\title{
PERMASALAHAN DAN UPAYA PENGEMBANGAN KAJIAN ISLAM MULTIDISIPLINER DI PASCASARJANA UNIVERSITAS ISLAM NEGERI (UIN) SUNAN AMPEL SURABAYA
}

\author{
Khoirun Niam \\ Universitas Islam Negeri Sunan Ampel Surabaya \\ Email: khoirunniam@uinsby.ac.id \\ Masdar Hilmy \\ Universitas Islam Negeri Sunan Ampel Surabaya \\ Email: masdar.hilmy@gmail.com
}

\begin{abstract}
The transformation of IAIN Sunan Ampel Surabaya to UIN Sunan Ampel Surabaya has an impact on changing the epistemology of science. The choice of twin towers as the paradigm needs to be translated to various levels of academic practice, so that the persons of academic community in UIN Sunan Ampel can understand and implement the paradigm. The studies in UIN Sunan Ampel also must be oriented to the paradigm. One of them is in Postgraduate Program, which seeks to develop inter, multi and trans-disciplinary Islamic studies at the level of $\mathrm{PhD}$ program. This study found that (1) most of the Stakeholders Postgraduate Program of UIN Sunan Ampel Surabaya have good understanding of inter and multidisciplinary Islamic studies; (2) the problems in implementing the inter and multidisciplinary Islamic studies are in four aspects: aspects of students, aspects of lecturers, aspects of curriculum, and aspects of carrying capacity and policies.
\end{abstract}

Keywords: Islamic Studies; interdisciplinary studies; multidisciplinary studies; transdisciplinary studies.

\section{Pendahuluan}

Kajian Islam di Perguruan Tinggi Keagamaan Islam (PTKI) Indonesia mengalami dinamika, yang sejalan dengan tuntutan dan tantangan zaman yang dihadapinya. Pada saat awal berdiri, kajian 
Islam diorientasikan pada pemenuhan kebutuhan untuk mempersiapkan calon-calon tenaga kepegawaian di Departemen Agama Republik Indonesia, ${ }^{1}$ sebagaimana terefleksi pada lembaga kajian Islam kedinasan ADIA. Saat lembaga kajian Islam berwujud sebagai Institut Agama Islam Negeri (IAIN), orientasi kajian diarahkan pada pendalaman aspek-aspek ajaran Islam yang terwujud dalam lima fakultas, yaitu Dakwah, Ushuluddin, Syari'ah, Tarbiyah, dan Adab. Kemudian muncul inisiatif dari para pengambil kebijakan untuk melakukan transformasi orientasi kajian Islam di pendidikan tinggi. Wujudnya berupa injeksi semangat kajian Islam yang lebih komprehensif. Disiplin ilmu yang dikaji tidak hanya pada wilayah kajian agama semata, tetapi juga mencakup ilmu-ilmu umum yang bernuansa keislaman, seperti

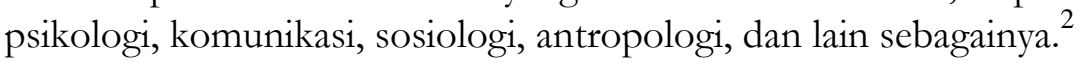

Belakangan ini transformasi IAIN ke dalam wujud Universitas Islam Negeri (UIN) telah dilakukan. Transformasi itu dilakukan atas dasar kesadaran umat Islam atas pentingnya penguasaan pengetahuan dan teknologi dalam menyesuaikan diri dengan akselerasi perubahan zaman yang cepat. Kalau dulu IAIN berfungsi sebagai lembaga keagamaan dan keilmuan, maka dengan dilakukannya transformasi ke UIN, upaya untuk memperkuat fungsi keilmuan menjadi lebih nyata. Pendekatan kajiannya pun juga lebih variatif. Tidak saja kajian normatif doktrinal yang dikedepankan, tetapi juga kajian akademis sosiokultural yang sejalan dengan kontek historis dan tantangan kelembagaannya. Hal ini yang mendorong munculnya kajian yang tidak saja dalam disiplin ilmu keislaman, tetapi juga kajian antardisiplin ilmu dan lintas disiplin ilmu.

Pada saat UIN Sunan Ampel Surabaya masih dalam bentuk IAIN, Nur Syam selaku rektor mempunyai komitmen kuat untuk mengawal kajian Islam multidisipliner ini. Hal itu dapat dilacak dari visi misi IAIN Sunan Ampel saat itu yang terumuskan dalam statuta: sebagai institusi yang diharapkan menjadi pusat

\footnotetext{
${ }^{1}$ M. Atho Mudzhar, "In the Making of Islamic Studies in Indonesia (in Search for a Qiblah)", makalah disampaikan dalam Seminar Internasional Islam in Indonesia: Intellectualization and Social Transformation Jakarta, 23-24 November 2000), 2.

2 Masdar Hilmy dan Akh. Muzakki, Dinamika Baru Studi Islam (Surabaya: Arkola, 2005), 53-54.
} 
pengembangan ilmu keislaman multidisipliner. Dari visi ini kemudian di-breakdown dalam beberapa misi, yaitu sebagai pusat pengembangan ilmu keislaman multidisipliner, sebagai pusat penelitian ilmu keislaman multidisipliner dan sebagai pusat pengembangan masyarakat yang islami, cerdas dan kompetitif.

Di sinilah keinginan kuat terhadap kajian Islam multidisipliner itu dapat dilacak dari lembaga ini. Nur Syam menyatakan bahwa "menilik terhadap visi dan misi IAIN Sunan Ampel, maka pantaslah kalau seluruh civitas akademika IAIN Sunan Ampel akan terus berjuang untuk mewujudkan cita-cita sebagai pusat pengembangan keilmuan keislaman multidisipliner yang menjadi tujuan tersebut". 3

Sejalan dengan itu, pemerintah melalui Perpres Nomor 8 Tahun 2012 tentang Kerangka Kualifikasi Nasional Indonesia (KKNI) membuat ketentuan untuk mengatur kerangka penjenjangan kualifikasi kompetensi yang dapat menyandingkan, menyetarakan, dan mengintegrasikan antara bidang pendidikan dan bidang pelatihan kerja, serta pengalaman kerja dalam rangka pemberian pengakuan kompetensi kerja sesuai dengan struktur pekerjaan di berbagai sektor. Yang diatur adalah sembilan jenjang kualifikasi, dimulai dari jenjang satu sebagai jenjang terendah sampai dengan jenjang sembilan sebagai jenjang tertinggi. Kualifikasi lulusan pada lulusan Diploma IV atau Sarjana Terapan dan Sarjana paling rendah setara dengan jenjang enam; lulusan pendidikan profesi setara dengan jenjang tujuh atau delapan; lulusan Magister Terapan dan Magister paling rendah setara dengan jenjang delapan; lulusan Doktor Terapan dan Doktor setara dengan jenjang sembilan.

Pascasarjana UIN Sunan Ampel Surabaya mempunyai tugas dan amanat untuk dapat mengimplementasikan kajian Islam sebagimana yang diatur oleh Perpres Nomor 8 Tahun 2012 itu. Kata kuncinya adalah Kajian Islam Multidisipliner. Permasalahannya adalah apakah pendekatan ini cukup dipahami oleh para pemangku kepentingan di Pascasarjana UIN Sunan Ampel Surabaya? Apakah para pengambil kebijakan cukup memahami kajian Islam multidisipliner ini? Bagaimana mereka merealisasikan dalam bentuk aturan dan dokumen pendidikannya? Apakah

\footnotetext{
3 Nur Syam, "Membangun Keilmuan Islam Multidisipliner", http:// nursyam.uinsby.ac.id/?p=754, diakses tanggal 6 Mei 2018.
} 
mahasiswa juga memahami aturan kajian keilmuan di perguruan tinggi yang harus mengedepankan pendekatan inter, multi, dan transdisipliner? Permasalahan ini mempunyai sisi strategis untuk dapat dipecahkan dalam kerangka penelitian terapan dan pengembangan agar nantinya dapat menemukan alternatif model kajian Islam multidisipliner yang dapat diimplementasikan di Pascasarjana UIN Sunan Ampel Surabaya.

Melihat permasalahan diatas, fokus penelitian ini diarahkan pada: (1) Bagaimana pemahaman stakeholder Pascasarjana UIN Sunan Ampel Surabaya terhadap kajian Islam Multidisipliner? (2) Permasalahan apa saja yang dihadapi Pascasarjana UIN Sunan Ampel Surabaya dalam mengimplementasikan Kajian Islam Multidisipliner? dan (3) Bagaimana desain kajian Islam multidisipliner yang tepat untuk dapat diimplementasikan di Pascasarjana UIN Sunan Ampel Surabaya?

Secara teoritis, penelitian ini dapat memberikan wacana dan mengisi sisi metodologi dalam mengkaji Islam pada level pascasarjana. Secara praktis, penelitian ini akan dapat memberi arah, orientasi, dan pendekatan baru bagi pelaksanaan kajian Islam di pascasarjana. Arah baru akan dapat ditemukan dengan adanya evaluasi terhadap pelaksanaan kajian Islam yang diterapkan saat ini. Kemudian orientasi akan dapat ditemukan dengan mengacu pada kepentingan stakeholder dan tuntutan dari peraturan maupun perundang-undangan yang berlaku serta tuntutan pemenuhan distingsi lembaga. Dengan mempertimbangkan arah dan orientasi itu, maka pendekatan akan dapat dipilih secara tepat. Karena penelitian ini merupakan penelitian kualitatif dan pengembangan, maka produk akhir yang dinginkan berupa kajian akademis tentang kajian Islam multidisipliner di Pascasarjana UIN Sunan Ampel Surabaya dan desain kajian Islam multidisipliner dalam bentuk Dokumen Pendidikan yang berisi: spesifikasi program, learning outcome, metode pembelajaran, dan struktur kurikulum.

Untuk menjamin hasil, penelitian ini dirancang melalui tiga tahap, mengikuti model penelitian Research and Development Model $\mathrm{R}$ and $D$ versi Sukamto yang terdiri dari tahap konseptualisasi, inisiasi, implementasi dan institusionalisasi. Tahap konseptualisasi dilakukan dimulai dengan pemetaan terhadap tingkat pemahaman stakeholder pascasarjana UIN Sunan Ampel Surabaya terhadap konsep kajian Islam multidisipliner. Kemudian dilanjutkan dengan 
penetapan ruang lingkup; sektor, jenjang, aras/level dari kajian Islam multidisipliner. Inventarisasi, analisis dan sintesis hasil-hasil penelitian dan kebijakan pengembangan yang lalu juga dilakukan. Begitu juga dengan melakukan penetapan visi pengembangan kajian Islam multidisipliner dalam skala makro, mikro dan dalam kerangka yang operasional.

Tahap inisiasi dilakukan dengan mempersiapkan ketersediaan SDM (peneliti, akademisi dan analis) yang dilanjutkan dengan sosialisasi dengan melibatkan stakeholder Pascasarjana UIN Sunan Ampel Surabaya yang terkait dengan penelitian ini. Tahap implementasi dilakukan dengan mempertimbangkan prinsipprinsip, problem riil, sasaran pengembangan, bersifat ongoing, dan melibatkan semua stakeholder Pascasarjana UIN Sunan Ampel Surabaya. Sedangkan tahap institusionalisasi hasil pengembangan dilakukan dengan mengakomodasikan melalui pelembagaan ke dalam struktur dan sistem yang ada di Pascasarjana UIN Sunan Ampel Surabaya.

Data yang akan dicari dalam penelitian ini adalah data-data teoritis yang berhubungan dengan kata kunci Kajian Islam, Kajian Islam Interdisipliner, Kanjian Islam Multidisipliner dan Kajian Islam Transdisipliner, demikian juga data tentang pemahaman stakeholder Pascasarjana UIN Sunan Ampel Surabaya terhadap eksistensi kajian Islam multidisipliner, serta data tentang permasalahan yang dihadapi Pascasarjana UIN Sunan Ampel Surabaya dalam mengimplementasikan kajian Islam multidisipliner.

Penelitian dan kajian tentang Islamic Studies, kajian Islam multidisipliner dan sejenisnya, telah pernah dilakukan baik secara langsung membahas masalah itu ataupun secara tidak langsung. Setya Yuwana Sudikan, misalnya, melakukan kajian tentang Pendekatan Interdisipliner, Multidisipliner, dan Transdisipliner dalam Studi Sastra. Kajian ini berkontribusi memberikan pemahaman terhadap penggunaan pendekatan interdisipliner, pendekatan multidisipliner, pendekatan transdisipliner, dan pendekatan krosdisipliner dalam mengkaji suatu ilmu.

Masdar Hilmy dan Akh. Muzakki (2005), menulis Dinamika Baru Studi Islam yang di dalamnya membahas tentang dinamika dan pendekatan dalam mengkaji Islam baik yang dilakukan di Barat maupun di dunia Islam, termasuk Indonesia. Sementara Mark Woodward, pernah mengkaji tentang "Islamic and religious 
studies: Challenges and Opportunities for Twenty-first Century Indonesia", yang terbit di Journal of Indonesian Islam; ${ }^{4}$ M. Luthfi Musthofa dan Helmi Syaifuddin (eds.), memfokuskan pada kajian bagaimana upaya integrasi atara ilmu dan agama dalam buku yang berjudul Intelektualisme Islam: Melacak. Akar-akar Integrasi Ilmu dan Agama; ${ }^{5}$ Amin Abdullah bahkan lebih eksplisit mengaitkan atara kajian Islam dan kajian ilmu-ilmu sosial dan humaniora dengan judul artikelnya "Islam as a Cultural Capital in Indonesia and the Malay World: A Convergence of Islamic Studies, Social Sciences, and Humanities", terbit di Journal of Indonesian Islam; ${ }^{6}$ dalam bentuk buku secara khusus, Amin Abdullah menulis Islamic Studies di Perguruan Tinggi, dan masih banyak lagi kajian yang dilakukan baik oleh ilmuwan Indonesia maupun ilmuwan mancanegara.

\section{Pemahaman Stakeholder tentang Kajian Islam Inter dan Multidisipliner}

Perihal kajian Islam inter dan multidisipliner, akhir-akhir ini mengemuka seiring dengan diterapkannya kurikulum KKNI yang mengamanatkan level sembilan doktoral untuk lebih memperdalam keilmuannya secara inter dan multidisipliner, bahkan transdisipliner. Kajian Islam level doktoral tidak hanya mengkaji Islam dari satu sisi disiplin ilmu, melainkan dari dua atau tiga disiplin keilmuan sekaligus untuk satu tema kajian Islam. Beberapa mahasiswa program doktoral (S3) UIN Sunan Ampel, terutama yang pernah mengikuti perkuliahan Metodologi Studi Islam yang diampu oleh Prof. M. Amin Abdullah (UIN Sunan Kalijaga) merasakan betapa pentingnya mengkaji tema keislaman dengan berbagai sudut pandang keilmuan, sebagai bentuk kajian baru yang lebih fresh. Menurut Sulanam, perkuliahan Amin Abdullah, selain dihantarkan secara serius, juga melihat sisi-sisi metodologis perkembangan kajian Islam di berbagai belahan dunia. Peta-peta

\footnotetext{
${ }^{4}$ Mark Woodward, "Islamic and religious studies: Challenges and Opportunities for Twenty-first Century Indonesia”, Journal of Indonesian Islam; Vol. 3, No. 1 (2009), 1-34.

${ }^{5}$ M. Luthfi Musthofa dan Helmi Syaifuddin (eds.), Intelektualisme Islam: Melacak Akar-akar Integrasi Ilmu dan Agama (Malang: LKQS, UIN Malang, 2007).

${ }^{6}$ Amin Abdullah, "Islam as a cultural capital in Indonesia and the Malay World: A Convergence of Islamic Studies, Social Sciences and Humanities", Journal of Indonesian Islam, Vol. 11, No. 2 (2017), 307-328.

7 Amin Abdullah, Islamic Studies di Perguruan Tinggi: Pendekatan IntegrarifInterkonektif (Yogyakarta: Pustaka Pelajar, 2006).
} 
mengenai perkembangan kajian Islam dilihat secara metodologis, temuan-temuannya dibahas baik dari sisi biografi intelektual, konteks sosial penemuan, maupun rentang sejarah penemuan dan kontribusinya bagi perkembangan keilmuan keislaman. ${ }^{8}$

Menurutnya, posisi inter dan multidisipliner dapat dinarasikan secara kongkret dalam mata kuliah ini. Setiap pertemuan perkuliahan disajikan dengan melihat apa yang baru dari topik yang sedang dibahas, bagaimana kebaruan itu ditemukan, metode apa yang digunakan, siapa penemu kebaruan kajian tersebut, bagaimana latar belakang keilmuan dan sosialnya, bagaimana pula konteks masyarakat pada saat itu sehingga penemuan baru tersebut betulbetul memiliki kontribusi bagi pemecahan problem kemanusiaan. Secara umum perkuliahan-perkuliahan yang diselenggarakan di program S3 sudah mengarah pada penekanan aspek inter dan multidisipliner. Namun demikian, beberapa pertemuan perkuliahan dan perkuliahan tertentu masih belum sepenuhnya dapat dikatakan berhasil mengantarkan mahasiswa untuk selalu ingat dan memahami secara utuh apa itu inter dan multidisipliner dalam kajian Islam, sehingga pada saat-saat khusus terdapat perkuliahan yang tidak maksimal. ${ }^{9}$

Menyikapi hal ini, salah seorang alumni S3 UIN Sunan Ampel juga tidak menampiknya. Ia memberikan deskripsi bahwa tidak semua yang tampil membawakan matakuliah tersebut juga dapat menguasai secara tuntas materi-materi dan kebaruan dari materimateri yang disajikan, "ya kadang-kadang ada pula dosen yang pada pertemuan keempat dan selanjutnya sudah kehabisan bahan, sehingga yang disajikan mengulang pertemuan sebelumnya". ${ }^{10}$ Sarannya, seyogiyanya mahasiswa, apalagi sudah level doktoral lebih proaktif menggali dan mencari sendiri topik-topik yang sedang menjadi garapannya, sehingga dosen dapat ditempatkan sebagai mitra atau second opinion dalam memperkuat kajiannya. "Memang harus diakui tidak semua dosen juga melakukan update

\footnotetext{
8 Sulanam (Mahasiswa S3 Angkatan 2017), Wawancara, 2 Agustus 2018.

${ }^{9}$ Sulanam, Wawancara, 2 Agustus 2018.

10 Mukhammad Zamzami (Alumni S3 UIN Sunan Ampel), Wawancara, 9 Agustus 2018, di Perpustakaan Pascasarjana UIN Sunan Ampel. Zamzami adalah alumni yang sekarang menduduki posisi sebagai Ketua Program Studi (Kaprodi) Aqidah dan Filsafat Islam (AFI). Dalam kesehariannya menjalankan tugas sebagai Kaprodi dan dosen, nalar inter dan multidisipliner ia gunakan untuk merangsang perkuliahan mahasiswanya.
} 
keilmuan, juga tidak selamanya dosen saat ditempatkan untuk mengampu mata kuliah tertentu, background keilmuannya berada pada posisi yang multidisipliner. Dalam posisi yang seperti ini, mahasiswa tentu harus lebih banyak menggali secara mandiri". ${ }^{11}$

Dari sisi pemahaman tentang inter dan multidisipliner kajian Islam, dapat dinarasikan bahwa sebagian besar level manajemen, dosen, tenaga pendukung maupun mahasiswa sudah memahaminya. Penilaian ini didasarkan pada sejumlah respon informan $^{12}$ yang secara umum menyebutkan kata kunci multidisipliner adalah memahami topik tertentu (kajian Islam) dengan beberapa sudut pandang keilmuan (disiplin ilmu). Sebagai gambaran, sebagaimana yang dikemukakan oleh petugas perpustakaan pascasarjana, adalah melalui tingkat permintaan kebutuhan mahasiswa terhadap sumber dan bahan bacaan. "Seringkali mahasiswa itu minta buku ini, buku itu, yang sepertinya tidak punya kaitan langsung dengan kajian Islam. Misalnya buku sosiologi, buku psikologi, buku sejarah. Tapi setelah banyak permintaan model demikian, saya jadi paham, mungkin saja bukubuku itu dipakai sebagai bahan untuk melihat tema khusus keislaman dari sudut pandang yang bukan keislaman". ${ }^{13}$ Jawaban lumayan gamblang dicontohkan oleh Ahmad Nur Fuad. ${ }^{14}$ Menurut Fuad, multidisipliner adalah pengkajian terhadap topik keislaman tertentu dari sudut pandang rumpun keilmuan, semisal rumpun keilmuan sosial-humaniora. Ia mencontohkan, jika seseorang melakukan kajian keislaman dengan melihatnya dari sudut politik, ekonomi, sosiologi, dan sejarah, maka ia telah melakukan kajian keislaman multidisipliner.

Jika seseorang melakukan kajian terhadap topik sosiologi hukum Islam, dengan menggunakan sudut pandang keilmuan

\footnotetext{
11 Mukhammad Zamzami, Wawancara, 10 Agustus 2018 di depan Ruang Prodi AFI.

12 Respon informan tidak dituliskan semua dalam laporan ini, mengingat wawancara, yang dilakukan sifatnya cepat dan to the point pada pemahaman tentang apa itu kajian Islam inter dan multi disipliner. Narasi di atas adalah generalisasi jawaban informan yang disampaikan pada pewawancara.

13 Isna Fistiyanti (Petugas Perpustakaan Pascasarjana), Wawancara, 9 Agustus 2018 di ruang Perpustakaan

${ }^{14}$ Saat ini Ahmad Nur Fuad menjabat sebagai Wakil Direktur Pascasarjana, setelah sebelumnya sebagai Kaprodi Studi Islam Program S3, UIN Sunan Ampel Surabaya.
} 
sosiologi dan keilmuan hukum Islam, maka ia sejatinya telah melakukan kajian Islam interdisipliner. Jika kajian itu interdisipliner, secara otomatis ia sudah multidisipliner. "Saya kira dalam hal ini saya sedikit berbeda dengan pemahaman temanteman dosen lainnya". ${ }^{15}$ Adapun kajian yang tergolong transdisipliner adalah kajian terhadap topik keislaman ditinjau dari antarrumpun bidang ilmu. Ia mencontohkan disertasi yang membahas tentang waria ditinjau dari sudut pandang medis dan fiqh. Tinjauan terhadap waria dari sudut pandang fiqh masuk rumpun ilmu sosial-humaniora, sedangkan dari sudut pandang ilmu medis masuk dalam rumpun ilmu alam.

Senada dengan Fuad, melalui ceritanya, Sulanam menuturkan pada saat menunggu dimulainya ujian kualifikasi lisan, ${ }^{16}$ Rofhani ${ }^{17}$ memberikan gambaran bahwa tema yang diangkatnya dapat dikatakan sudah multidisipliner. Tema transmisi ideologi ke suatu lembaga tertentu sejatinya juga akan mengungkap proses transmisi yang melibatkan faktor sosiologis, psikologis, politis dan ideologis. Keempat faktor tersebut merupakan tinjauan bidang ilmu dalam satu rumpun ilmu sosial-humaniora, yang karenanya dapat dianggap multidisipliner. ${ }^{18}$

Semenatara itu, terdapat variasi dalam tingkat pemahaman mahasiswa S3 Studi Islam (Dirasah Islamyiah). Rasyida Arsjad (Mahasiswa Angkatan 2017) mengajukan judul proposal disertasi dalam mata kuliah Seminar Proposal yang diampu oleh Dr. Phil. Khoirun Niam sebagai berikut: "Diaspora Muslim Bawean Abad XIX-XX di Asia Tenggara sebagai Kultur Keislaman Nusantara". Dari judul itu tampak bahwa mahasiswa menggunakan pendekatan historis saja, sehingga jelas bahwa implementasi pemahaman terhadap kajian Islam multidisipliner dalam proposal disertasi yang

\footnotetext{
15 Ahmad Nur Fuad, Wawancara, 9 Agustus 2018, di ruang dosen Program Pascasarjana (PPs) UIN Sunan Ampel, Gedung Twin Tower B lantai 2. Penjelasan umum mengenai interdisipliner adalah kajian terhadap suatu topik keislaman ditinjau dari sudut pandang bidang ilmu intern keislaman, seperti sudut pandang ilmu tafsir, fiqh, balaghoh, ataupun hadist.

${ }^{16}$ Sesi ujian kualifikasi lisan, Program Doktoral Kajian Islam UIN Sunan Ampel Surabaya, tanggal 24 Agustus 2018, pukul 10.00 WIB di lantai 3 Gedung Pascasarjana UIN Sunan Ampel.

${ }^{17}$ Sekretaris Program Doktoral Studi Islam, yang pada saat ujian kualifikasi lisan bertindak sebagai Ketua Penguji.

${ }^{18}$ Keterangan Rofhani, sebagaimana diceritakan oleh Sulanam, 25 Agustus 2018.
} 
diajukan belum tampak. Untuk menghasilkan kajian Islam inter dan multidisipliner mahasiswa disarankan untuk melakukan perubahan judul dengan mempertimbangkan berbagai disiplin ilmu yang menjadi sudut pandang penelitian. Judul yang disarankan menjadi: "Diaspora Muslim Bawean di Asia Tenggara; Kajian Historis, Sosiologis, dan Budaya atas Tradisi Merantau Muslim Bawean dan Kontribusinya terhadap Kemajuan Ekonomi dan Pendidikan Masyarakat Bawean Kontemporer". Revisi judul ini memperlihatkan kajian terhadap Muslim Bawean didekati dengan empat perspektif keilmuan, yaitu Sejarah, Sosiologi, Budaya, Ekonomi, dan Pendidikan. Karena perspektif kajian menggunakan empat perspektif keilmuan, maka kajian Muslim Bawean dapat dikatakan sebagai kajian Islam multidisipliner. ${ }^{19}$

Dalam kasus judul proposal disertasi yang diajukan mahasiswa atas nama Nuril Hidayati pada kelas Seminar Proposal, didapati judul sebagai berikut: "Episteme Hijaber; Membedah Nalar Fashion Muslimah Indonesia". Dari judul itu tampak bahwa pemahaman mahasiswa terhadap kajian Islam inter dan multidisipliner belum terwujud dalam produk rencana proposal disertasi. Fashion Muslimah Indonesia dilihat dari perspektif filosofis yang tampak dari kata kunci "Episteme Hijaber". Untuk itu, mahasiswa disarankan untuk melakukan perubahan judul menjadi "Fashion Muslimah Indonesia; Membedah Nalar Teologis, Historis, Sosiologis, Politis dan Ekonomis Fenomena Hijaber". Alternatif judul yang disarankan menunjukkan perspektif keilmuan yang bersifat beragam yaitu teologis, historis, sosiologis, politis, dan ekonomis. $^{20}$

Sedangkan dalam rencana proposal yang diajukan mahasiswa atas nama Rizqa Ahmadi, tampak bahwa judul telah menggambarkan kajian Islam multidisipliner. Dari judul yang berbunyi "Resepsi dan Ekspresi atas Hadits Nabi Pengamal Tasawuf Kultural di Jawa Timur; Studi Living Hadis Jamaah Tarekat Siddiqiyah, Sholawat Wahidiyah dan Dzikrul Ghafilin", terdapat empat perspektif keilmuan yang dijadikan pisau analisis untuk membedah permasalahan penelitian, yaitu Hadīth, Tasawuf, Budaya/Antropologi, dan Sosiologi. Namun demikian, perlu ada

\footnotetext{
${ }^{19}$ Dokumen Perkuliahan Seminar Proposal yang diampu oleh Dr. Phil. Khoirun Niam, 2018.

${ }^{20}$ Ibid.
} 
perbaikan redaksi judul yang disarankan sebagaimana berikut: "Tasawuf Kultural di Jawa Timur; Resepsi dan Ekspresi Jamaah Tarekat Siddiqiyah, Sholawat Wahidiyah dan Dzikrul Ghafilin atas Hadits Nabi". 21

Dari paparan di atas, diketahui bahwa tingkat pemahaman mahasiswa terhadap eksistensi kajian Islam inter dan multidisipliner di Pascasarjana UIN Sunan Ampel Surabaya terdapat variasi dalam bentuk pemahaman, sebagaimana tampak dalam ekspresi rencana proposal disertasi mereka.

\section{Problematika Implementasi Kajian Islam Inter dan Multi- disipliner}

Untuk memudahkan pembahasan problematika implementasi kajian Islam inter dan multidisipliner di Pascasarjana UIN Sunan Ampel, akan dilihat dari empat aspek, yakni: aspek mahasiswa, aspek dosen, aspek kurikulum, dan aspek daya dukung dan kebijakan. Aspek mahasiswa penting dilihat mengingat mahasiswa adalah pelaku utama (subyek aktif) dalam pembelajaran orang dewasa (andragogy). Keseriusan mahasiswa dalam hal implementasi kajian inter dan multidisipliner menjadi perhatian penting, karena keberhasilan implementasi ini sebagian besar bergantung pada mereka. Aspek dosen juga merupakan hal penting, karena interaksi, proses diskusi dan penajaman kajian, serta proses pembimbingan akademik dilakukan oleh dosen kepada mahasiswa.

Umumnya, dari proses interaksi ini, ketidakberhasilan mencapai suatu tujuan akan berakibat pada situasi saling menyalahkan. Bisa saja mahasiswa akan menyalahkan dosen karena performance yang tidak optimal dalam memberikan rangsangan kepada mahasiswa, untuk lebih giat dalam menggali hal-hal baru dalam setiap kajian dan tatap mukanya. Di sisi lain, dosen juga akan nggerundel dan menyalahkan mahasiswa karena tidak mampu mengikuti ritme dan update terhadap kajian-kajian mutakhir yang ia ampu, atau bisa juga karena background keilmuan mahasiswa tidak kompatibel dengan area kajian yang ditekuni kini. Dua entitas ini dapat dikatakan sebagai ujung tombak dalam penentuan keberhasilan perkuliahan doktoral yang mengimplementasikan kajian inter dan multidisipliner. Keduanya memiliki peluang yang sama dalam membanding-bandingkan satu dengan yang lain.

21 Ibid. 
Dosen akan membandingkan kualitas mahasiswa kelas tertentu dengan kualitas mahasiswa kelas lain atau sebelumnya. Mahasiswa juga dapat membandingkan antara dosen tertentu dengan dosen lain.

Sebagai jembatan problematika dua entitas tersebut, kehadiran kurikulum yang diharapkan dapat memandu keberhasilan implementasi kajian inter dan multidisipliner memiliki arti penting sebagai pedoman standar pencapaian dan keberhasilan pembelajaran. Kurikulum yang didesain dengan baik, tertata tahapan pencapaiannya, baik dari sisi waktu maupun content, serta terpantau dari sisi evaluasinya, dapat memberi arah bagi proses perkuliahan.

Aspek keempat yang tak kalah penting adalah aspek daya dukung dan kebijakan. Aspek ini memberikan garis besar yang sifatnya mendukung baik dari sisi birokrasi kampus, penyediaan sumber belajar online maupun offline, atau prosedur-prosedur khusus yang dirancang oleh kampus dalam bentuk kebijakan, seperti dukungan dan fasilitasi klinis penemuan tema, pemilihan sumber dan bahan mutakhir, penelusuran sumber referensi babon, akses terhadap sumber-sumber bacaan, atau penyusunan proposal disertasi.

\section{Problematika Implementasi: Aspek Mahasiswa}

Ada banyak faktor penentu keberhasilan mahasiswa dalam menempuh studi, salah satunya adalah faktor kemampuan akademis untuk mendukung penyelesaian riset doktoral yang ia tempuh. Riset doktoral membutuhkan kajian inter dan multidisipliner, sehingga keilmuan yang telah diperoleh semasa jenjang Magister (S2) sangat menentukan pada saat melakukan riset S3. Jadi, raw material input S3 kajian Islam seharusnya telah memiliki kemampuan dasar keislaman yang kuat, sehingga ia hanya perlu memperdalam dan memperluas kajian secara multidisiplin ilmu.

Terkait raw material input, yang masuk studi ke jenjang S3 tidak semuanya memiliki kesiapan akademis untuk inter dan multidisipliner. Hal ini disebabkan oleh jenjang S1 dan S2 yang ditempuh sebelumnya diarahkan pada monodisiplin. Salah seorang mahasiswa angkatan 2016 menyatakan, sebetulnya secara pemahaman sudah dapat menerima untuk berpikir dan menuangkan gagasan secara multidisipliner, tetapi pengaruh kuat yang diperoleh saat berada di S1 dan S2 cukup sulit dipakai untuk 
menuangkan gagasan secara multidisipliner. Mujib Ridlwan mengatakan:

Seringkali pembahasan terhadap kajian-kajian yang saya lakukan akhirnya terkontaminasi dengan apa yang sudah saya peroleh sebelumnya. Ujung-ujungnya kembali ke situ. Jadi, jika mau hasil yang baik, sebetulnya teman-teman yang mau kuliah S3 itu sudah terencana dan tertata sejak S1. Misalnya, saat S1 kajiannya murni monodisiplin, ke jenjang S2 sudah setengah multidisiplin, baru saat S3 sudah berpikir dan mengkaji secara multidisiplin. Mungkin itu baru bisa baik. ${ }^{22}$

Bagi Mujib Ridlwan, dalam posisi yang sulit move on dari pengaruh studi sebelumnya, posisi dosen pembimbing dibutuhkan oleh mahasiswa untuk memberikan narasi dan penjelasan tentang mana saja kajian yang bisa dilakukan secara multidisiplin. Mahasiswa, meski sebetulnya ia sudah tahu, tetapi pada saat yang sama ia juga tidak sadar bahwa yang dilakukan itu adalah multidisiplin. Di sinilah posisi penting dosen pembimbing, memberikan arahan, penyadaran, dan penajaman terhadap kajian multidisiplin yang dilakukan oleh mahasiswa.

Masalahnya, proses pembimbingan, baik di sisi mahasiswa maupun di sisi dosen, terkendala karena duanya memiliki kesibukan yang tinggi. Kalau mahasiswa jarang ke kampus dan tidak memiliki kekedakatan dengan dosen, tentu tidak bisa mendapat pembimbingan di luar jam pembimbingan yang sudah terjadwal. Lagi-lagi, mahasiswa harus mampu berjuang untuk menyelesaikan kajiannya sendiri. Problem lain adalah mahasiswa Prodi Studi Islam yang tidak berangkat dari monodisiplin ilmu yang sama, juga berakibat pada daya serap dan daya analisis yang berbeda-beda. Dalam satu kelas Studi Islam bisa terdiri dari mahasiswa yang berasal dari disiplin ilmu Dakwah, Ushuluddin, Tarbiyah, Sejarah Islam maupun Syariah.

Fakta di atas dialami oleh Sulanam, yang merasa bahwa keilmuan dari disiplin ilmu Tarbiyah kurang mendapat tempat dalam kajian Islam di pertemuan-pertemuan perkuliahan. Umumnya perkuliahan lebih banyak bersinggungan dengan disiplin ilmu dari Ushuluddin, Adab, ataupun Syariah. Sehingga apa yang didiskusikan jauh dari ilmu-ilmu yang selama ini diperoleh sejak

\footnotetext{
22 Mujib Ridlwan (Mahasiswa S3 Angkatan 2016), Wawancara, via telepon pada 26 Agustus 2018.
} 
jenjang S1 maupun S2. ${ }^{23}$ Pengalaman yang demikian ini juga dirasakan oleh beberapa mahasiswa lainnya, di kelasnya.

Selain problem di atas, faktor penguasaan ilmu alat seperti bahasa juga menjadi kendala mendasar bagi mahasiswa S3, yang sejatinya lebih ditekankan pada perujukan ke sumber asal dan penelusuran pada temuan teoritik awal, yang lebih banyak berkembang di dunia Barat. Hampir sebagian besar mahasiswa merasa kesulitan untuk mencerna bahasa Inggris dengan baik. Ngatiyar, dalam salah satu kesempatan, mengungkapkan bahwa untuk sampai ke sumber pokok topik yang sedang dibahas, harus membaca terlebih dahulu beberapa artikel yang mengulas topik tersebut dalam bahasa Indonesia, ${ }^{24}$ kemudian melacak sumber asli dan memahaminya secara pelan-pelan.

\section{Problematika Implementasi: Aspek Dosen}

Dosen memiliki peran penting untuk menjembatani kebuntuan yang dialami mahasiswa dalam mengeksplorasi kajian keislaman tertentu secara inter dan multidisipliner. Jika melihat fakta problematik di atas, pembimbingan bagi mahasiswa agar mampu menggunakan multipendekatan dalam kajian Islam juga perlu diarahkan oleh dosen. Mahasiswa tidak harus dibiarkan mencari sendiri, tetapi juga perlu diberi target-target yang terstruktur dan terukur. Pada semester awal, penanaman kuat terhadap multidisipliner perlu diberikan kepada mahasiswa dengan mengkreasikan pembelajaran di ruang kelas secara ketat. Hal ini semata agar nalar multidisipliner terpatri dalam setiap gagasan yang diusung oleh mahasiswa di setiap momen diskusi kelas. Salah satu contoh praktis dari kegiatan yang terstruktur dan terukur dapat disimak dari proses perkuliahan Metodologi Studi Islam yang diampu oleh Amin Abdullah.

Pada matakuliah tersebut, pembagian tugas presentasi kelas telah ditentukan di muka, didasarkan pada pertemuan pertama yang berisi overview dan perkenalan masing-masing latar belakang akademis mahasiswa. Pada pertemuan berikutnya, pembagian tugas paper presentasi kelas telah diberikan berdasarkan penakaran kemampuan akademis mahasiswa. Setiap mahasiswa mendapat

\footnotetext{
${ }^{23}$ Sulanam, Wawancara, 2 Agustus 2018.

24 Ngatiyar (Mahasiswa S3 Angkatan 2017), Wawancara, via telepon 27 Agustus 2018.
} 
jatah dua kali penyusunan paper untuk tema tertentu secara individual, meski presentasinya berkelompok. ${ }^{25}$

Tema-tema dalam matakuliah Metodologi Studi Islam diarahkan untuk melihat bagaimana bangunan keilmuan yang ditelurkan oleh pemikir tertentu. Dalam berbagai cerita mahasiswa, Amin Abdullah tidak segan untuk memberikan kritik secara pedas kepada mahasiswa manakala paper yang ditulis tidak memberikan gambaran sebagaimana yang ia kehendaki. Fokus perkuliahan ini, yang lebih banyak mengulas tentang metodologi, diharapkan dapat menampilkan aspek metodologis yang digunakan oleh pemikir tertentu dalam melihat, mensistematisasi, dan kemudian menarik simpulan terhadap suatu problem kehidupan tertentu.

Selain topik perkuliahan, mahasiswa juga diminta menulis dari sudut pandang tertentu mengenai topik yang sedang dibahas. Tidak mudah untuk memahami sumber-sumber rujukan yang diberikan dalam perkuliahan ini, mengingat keseluruhan sumber ditulis dalam bahasa Inggris, sehingga dosen pengampu juga memberikan tekanan tertentu untuk memahami bab tertentu pada halaman tertetu dalam suatu buku rujukan. Sebetulnya, yang demikian ini memberikan ruang bagi mahasiswa agar bisa fokus pada pembahasan tertentu dalam suatu buku. ${ }^{26}$

Meski demikian, tidak keseluruhan mahasiswa memahami dengan baik apa tujuan yang dikehendaki dari matakuliah Metodologi Studi Islam ini. Matakuliah yang menitikberatkan pada keterbukaan pikiran dan keterbukaan multipendekatan dalam mengkaji Islam ini beberapa kali sempat gagal saat diskusi kelas. Kenyataan ini hampir dialami oleh keseluruhan kelas yang diampu oleh Amin Abdullah. Tidak jarang beberapa mahasiswa harus mengulang pembahasan dan mengulang menyusun makalah. ${ }^{27}$

\footnotetext{
${ }^{25}$ Lihat dokumen pribadi perkuliahan Sulanam, 2017.

26 M. Amin Abdullah, dosen pengampu, menginginkan atau paling tidak memberikan arah pada mahasiswa agar pembahasan dititikberatkan dengan merujuk pada halaman-halaman tertentu pada buku-buku di masing-masing topik. Penulisan makalah harus berisi narasi tentang permasalahan, prior research on topic, kerangka teori, metode, konsep dasar, dan kontribusinya dalam pengembangan ilmu pengetahuan. Lihat Bahan Rujukan penulisan working paper seminar kelas matakuliah Metodologi Studi Islam, M. Amin Abdullah, Semester Gasal 2017/2018.

27 Sulanam, Wawancara, 2 Agustus 2018.
} 
Pada kesempatan perkuliahan, Amin Abdullah sering menyampaikan kunci penting dalam perkuliahan Metodologi Studi Islam dengan mengungkapkan kata kunci fresh ijtihad, cross-reference, dan open minded. ${ }^{28}$ Beberapa kata kunci yang selalu disampaikan oleh Amin Abdullah dalam setiap pertemuan juga dijelaskan pada saat usai presentasi kelas. Ia selalu memberi penekanan terhadap apa yang baru yang ditawarkan oleh pemikir Muslim? Kenapa ia mendapatkan kebaruan dalam kajiannya? Simpulan yang selalu ia berikan adalah bahwa pemikir-pemikir Muslim dapat melakukan cross-reference, memasukkan pendekatan baru tanpa meninggalkan pendekatan lama sebagai basis kajian, sehingga fresh ijtihad berhasil diperoleh oleh pemikir tersebut. Seharusnya, melalui matakuliah ini, mahasiswa sudah memperoleh bekal yang cukup untuk berpikir dan melakukan kajian inter dan multidisipliner. Tiap pertemuan yang disajikan dengan selalu mengutarakan kata kunci di atas telah membekali mahasiswa untuk dapat mengkaji secara inter dan multidisipliner. Namun, jika melihat problematika mahasiswa pada poin di atas, tampaknya memang butuh tidak hanya sekali mengingatkan dan membekali mahasiswa dalam melakukan kajian Islam yang inter atau multidisipliner.

Setelah melihat fakta ideal di atas, ada juga beberapa dosen yang dianggap kurang dapat memberikan dorongan kuat kepada mahasiswa dalam membuka cakrawala inter dan multidisipliner. Pro kontra terhadap mono-multidisiplin ini sendiri tidak dapat dielakkan, mengingat kajian Islam tidak ditempatkan sebagai kajian yang tidak hanya melulu berkutat pada aspek doktrin, ajaran, maupun nilai. Bagi yang menolak multidisiplin, ada anggapan bahwa kajian Islam sebetulnya diarahkan pada penguatan bangunan tata nilai, sehingga rumusan-rumusan yang dituangkannya juga bersifat normatif. Keluhan itu disampaikan oleh Mukhammad Zamzami, alumni S3 UIN Sunan Ampel. Ia melihat beberapa dosen bahkan ada yang menolak hermeneutika, misalnya, sebagai salah satu pendekatan multidisiplin dalam tafsir al-Qur'ān. ${ }^{29}$ Kecenderungan-kecenderungan yang mengarah pada

\footnotetext{
${ }^{28}$ Lihat Sulanam, "Dari Mengaji ke Mengkaji; Catatan Reflektif untuk Guruku, Profesor Amin Abdullah", Tugas Catatan Reflektif untuk Matakuliah Metodologi Studi Islam, Semester Gasal 2017/2018 (Surabaya: Program Doktoral Kajian Islam UIN Sunan Ampel Surabaya, 2017), 3.

${ }^{29}$ Mukhammad Zamzami, Wawancara, 10 Agustus 2018.
} 
monodisiplin ini selanjutnya juga mempengaruhi mahasiswa dalam memantapkan jalan pikiran multidisiplinnya.

\section{Problematika Implementasi: Aspek Kurikulum}

Sebagaimana tertuang dalam buku pedoman penyelenggaraan pendidikan Pascasarjana UIN Sunan Ampel Surabaya, disebutkan bahwa visi program doktoral adalah menjadi pusat kajian ilmu-ilmu keislaman inter, multi dan transdisipliner yang unggul dan kompetitif bertaraf internasional pada tahun 2021. ${ }^{30}$ Mencermati rumusan visi tersebut, Prof. Abd. A'la, mantan Rektor UIN Sunan Ampel melihat bahwa program doktoral ini masih jauh dari harapan. Kajian Islam inter dan multidisipliner yang dikembangkan di S3 UIN Sunan Ampel seharusnya sudah pada level transdisipliner. ${ }^{31}$ Pandangan tersebut dapat dibenarkan, mengingat pada tahun 2021 Pascasarjana menargetkan bertaraf internasional. Alasan lain yang dapat digunakan adalah usia program doktor yang sudah lewat satu dekade, tetapi belum banyak menghasilkan karyakarya yang mengarah pada transdisipliner. ${ }^{32}$ Padahal kajian-kajian transdisipliner ini, sejatinya yang dibutuhkan untuk menjawab berbagai tantangan kemanusiaan terkhusus di Indonesia, yang rentan dengan persoalan yang berpangkal dari isu agama. Permasalahan yang dihadapi dalam menguatkan kajian inter, multi dan trandisipliner tidak saja berada di satu aspek, melainkan juga muncul di aspek input mahasiswa, proses, dosen, maupun kurikulum.

Masih menurut Abd. A'la, untuk mengimplementasikan penguatan kajian Islam inter, multi, dan transdisipliner, payung hukumnya merujuk pada KKNI level sembilan. Kurikulum terbaru ini perlu diterjemahkan ke dalam perkuliahan dengan cara penyamaan visi dan orientasi bagi dosen, pengelola dan mahasiswa. Pada pasal 5 huruf h payung hukum KKNI, disebutkan bahwa

\footnotetext{
${ }^{30}$ Buku Pedoman penyelenggaraan pendidikan pascasarjana UIN Sunan Ampel (Surabaya: UIN Sunan Ampel, 2018), 22, juga dapat diakses melalui http://mpai.uinsby.ac.id/wp-content/uploads/2018/08/pedoman-akademiks2-s3_2018-revised.pdf diakses pada 27 Agustus 2018.

31 Abd. A'la, Wawancara, 10 Agustus 2018, di Ruang Dosen Fakultas Adab dan Humaniora, UIN Sunan Ampel Surabaya.

32 Ahmad Nur Fuad menyebut bahwa disertasi yang dapat dikategorikan transdisipliner adalah pembahasan tentang waria ditinjau dari sudut pandang fiqh dan medis.
} 
lulusan program doktor terapan dan doktor setara dengan jenjang sembilan. ${ }^{33}$ Selain itu, Abd. A'la menawarkan pentingnya matakuliah pengembangan kreatifitas dan inovasi bagi mahasiswa. Menurutnya, matakuliah ini dapat dipakai oleh mahasiswa untuk menemukan dan mengenali berbagai peluang yang dapat dikreasikan dalam berbagai area kajiannya.

Untuk melihat bangunan kurikulum di program S3 UIN Sunan Ampel, di bawah ini dijelaskan mengenai sebaran matakuliah yang ditempuh oleh mahasiswa, baik yang sifatnya wajib maupun yang bersifat pilihan. ${ }^{34}$

Sebaran matakuliah yang mengikuti kurikulum 2014 ini diberikan kepada mahasiswa Studi Islam secara terprogram (paket). Pada kolom bertuliskan huruf $\mathrm{T}$ dan $\mathrm{Y}$ menunjukkan bahwa $\mathrm{Y}$ adalah wajib ditempuh oleh mahasiswa S3 Studi Islam. Sehingga pada semester pertama, mahasiswa menempuh lima matakuliah. Sedangkan pada semester kedua, mahasiswa menempuh sebanyak empat matakuliah termasuk seminar proposal. Matakuliah seminar proposal ini diberikan kepada mahasiswa guna membekali bagaimana cara menemukan ide, distingsi, problem akademik, dan kemudian menuangkan gagasannya dalam makalah.

Dari sisi kurikulum, jika dicermati, sebaran matakuliah pada semester pertama dan semester kedua sudah mencerminkan dukungan yang memadai bagi mahasiswa sebelum melakukan riset doktoral. Matakuliah Metodologi Studi Islam yang diberikan pada semester satu dapat dikatakan sebagai bekal guna membuka cakrawala dan membuka nalar inter, multi, maupun transdisipliner. Matakuliah lainnya diberikan untuk mendukung dan mengkayakan khazanah keilmuan yang mendukung wacana keislaman inter dan multidisipliner.

\footnotetext{
33 Peraturan Presiden Nomor 8 Tahun 2012 tentang Kerangka Kualifikasi Nasional Indonesia (KKNI). Dalam lampiran Perpes ini, dideskrisikan bahwa jenjang kualifikasi level sembilan adalah mampu mengembangkan pengetahuan, teknologi, dan/atau seni baru di dalam bidang keilmuannya atau praktek profesionalnya melalui riset, hingga menghasilkan karya kreatif, original, dan teruji; dan mampu memecahkan permasalahan ilmu pengetahuan, teknologi, dan/atau seni di dalam bidang keilmuannya melalui pendekatan inter, multi, dan transdisipliner.

34 Secara lebih rinci lihat http://siakadpasca.uinsby.ac.id/akademik/siakad/ index.php?page=list_kurikulum, diakses pada 27 Agggustus 2018.
} 
Secara konsepsi, urutan pemberian matakuliah mulai dari semester satu hingga semester dua ini sudah cukup sistematis dalam mendorong mahasiswa untuk melakukan kajian Islam inter dan multidisipliner. Akan tetapi, jika dijumpai fakta problematis sebagaimana dibahas dalam sub-bab di atas, maka itulah yang butuh dicarikan jalan keluar. Fakta bahwa mahasiswa belum sepenuhnya mampu berpikir multipendekatan, karena tidak berada dalam satu level keilmuan, atau karena memang tidak mampu melakukan analisis dengan multidisiplin, atau karena tidak memiliki perangkat yang cukup untuk memahami teks sumber asli yang ratarata berbahasa Inggris, haruslah dicarikan jalan keluar. Mungkin saja, jalan keluar itu dapat berupa asistensi kepada mahasiswa dalam menemukenali ide, fakta, atau gagasan kajiannya, atau dengan cara memperbanyak terjemahan sumber asli untuk kepentingan penguatan rujukan dan pemahaman dari sumber primer.

Jika pada semester satu sudah diberikan matakuliah Metodologi Studi Islam sebagai pembuka wawasan inter dan multidisipliner dengan kata kunci cross-reference, selanjutnya pada semester kedua diberikanlah matakuliah Proposal Disertasi. Matakuliah ini adalah proses praktis bagaimana menuangkan gagasan multidisipliner ke dalam bentuk tulisan proposal, yang dibimbing secara terarah dalam tatap muka perkuliah. Melihat hal ini, secara konsepsional sebetulnya kurikulum sudah disusun secara sistemik dalam mendorong mahasiswa untuk menghasilkan kajian yang inter dan multidisipliner.

Seharusnya, secara konsepsional pula, dukungan kurikulum yang dijadikan acuan untuk mengantarkan mahasiswa dalam menghasilkan karya kajian Islam yang inter dan multidisipliner telah diberikan oleh pihak penyelenggara pendidikan, dalam hal ini Program Pascasarjana UIN Sunan Ampel Surabaya. selain dukungan kurikuler, dukungan non-kurikuler juga diberikan kepada mahasiswa melalui kegiatan bimbingan teknis penulisan disertasi, kuliah umum, maupun seminar-seminar yang diselenggarakan oleh pascasarjana sebagai bekal pendukung dalam menyelesaikan studi.

Memasuki semester ketiga dan keempat, proses aktif berada di tangan mahasiswa. Sebagai subyek aktif, mahasiswa diberi keleluasaan untuk mengeksplorasi gagasan maupun memperdalam 
kajiannya. Tidak ada perkuliahan yang diselenggarakan pada semester ketiga dan keempat. Proses-proses dilakukan oleh mahasiswa secara terjadwal dari pihak penyelenggara, dan secara aktif dijalankan oleh mahasiswa sendiri. Sampai di sini, keleluasaan yang diberikan, yang sejatinya ditujukan agar mahasiswa memiliki cukup waktu untuk menghasilkan karya disertasi yang baik, tidak jarang juga malah membikin mahasiswa terlena. Proses asistensi yang longgar membuat mahasiswa semakin lupa dengan karya yang seharusnya lebih baik, dan justru berujung pada karya yang asalasalan.

Sepertinya, inilah problem yang harus dicarikan jalan keluar. Sampai pada titik di mana mahasiswa belum menemukan promotor, akibat belum disetujuinya proposal, mahasiswa nyaris tidak bersinggungan secara langsung dengan kampus pengelenggara program S3. Kualifikasi yang sepertinya mudah tetapi jika tidak disediakan proses pendampingan yang baik bagi mahasiswa, justru berakibat pada proses yang asal-asalan dan tidak jarang juga berakibat pada tidak terlaluinya proses kualifikasi ini, alias tidak dikerjakan oleh mahasiswa.

\section{Problematika Implementasi: Aspek Daya Dukung dan Kebi- jakan}

Secara prosedural, dukungan kebijakan disosialisasikan saat mahasiswa pertama kali masuk perkuliahan, pada kegiatan Orientasi Mahasiswa Baru. Pembekalan yang diberikan tidak hanya dalam bentuk orasi lisan, tetapi juga dalam bentuk pemberian buku pegangan akademik bagi mahasiswa pascasarjana. ${ }^{35}$ Sebagaimana dijelaskan diatas, dukungan selanjutnya diberikan dalam bentuk kegiatan non-kurikuler, berupa bimbingan teknis melalui seminar maupun pelatihan.

Dari sisi pengelola, dukungan dan prosedur administrasi yang begitu rumit dan banyak, tanpa didukung oleh tenaga yang banyak,

\footnotetext{
35 Saat mengikuti Orientasi Mahasiswa Baru, mahasiswa diberi dua buku: buku pedoman penyelenggaraan akademik pascasarjana dan buku pedoman penulisan makalah, proposal, tesis, dan disertasi. Sebagai contoh, lihat Program Pascasarjana UIN Sunan Ampel, Pedoman Penyelenggaraan Pendidikan Pascasarjana UIN Sunan Ampel Surabaya (Surabaya: UIN Sunan Ampel Surabaya, 2018); Program Pascasarjana UIN Sunan Ampel, Pedoman Penulisan Makalah, Proposal, Tesis, dan Disertasi UIN Sunan Ampel Surabaya (Surabaya: UIN Sunan Ampel Surabaya, 2018).
} 
juga berakibat pada penjadwalan tahapan kegiatan akademis yang tidak bisa cepat. Artinya, jika kualifikasi saja hanya diselenggarakan sekali dalam satu semester, maka mahasiswa yang tertinggal harus mengikuti kualifikasi pada semester berikutnya, begitu seterusnya. Itu bermakna, ada waktu satu semester yang hilang, yang tidak termanfaatkan dengan baik oleh mahasiswa.

Sebelum memasuki kualifikasi, dukungan berupa asistensi penentuan tema multidisipliner bagi mahasiswa juga problematis. Tampaknya, keruwetan yang ada di level mahasiswa, yang tidak mampu menemukan tema yang betul-betul inter dan multidisipliner, berdampak secara sistemik terhadap kegamangan pengajuan judul, penyusunan draf kualifikasi, hingga penyusunan proposal. Jika demikian, jalan keluar yang dapat ditempuh adalah pascasarjana menetapkan sejumlah tema pokok riset, yang bisa saja merujuk pada Arah Riset Keagamaan Nasional (ARKAN) yang dirumuskan oleh Kementerian Agama, maupun arah riset yang dirumuskan oleh UIN Sunan Ampel Surabaya, sebagai turunan dari arah riset keagamaan nasional. Arah riset ini selanjutnya menjadi payung dan dicapai secara bertahap oleh UIN Sunan Ampel melalui mahasiswanya. Konsekuensinya dibutuhkan gugus ad hoc yang secara khusus bertugas untuk menjamin ketercapaian arah riset tersebut, yang dititipkan melalui riset akademis mahasiswa di semua strata.

Selain beberapa problem di atas, problem yang tak kalah penting adalah berkaitan dengan akses ke sumber primer baik yang offline maupun online. Penelusuran mengenai ketersediaan dan keteraksesan sumber referensi dilakukan ke pihak pengelola perpustakaan pascasarjana. Isna Fistiyanti menyebutkan, kadangkadang ada mahasiswa yang minta disediakan item judul tertentu, tetapi karena pihak rekanan pengadaan buku tidak bisa menyediakan, maka hal tersebut tidak bisa dipenuhi. ${ }^{36}$ Berkaitan dengan pemanfaatan perpustakaan untuk pemenuhan kebutuhan sumber belajar dan bahan penyusunan makalah, Perpustakaan Pascasarjana mencatat rata-rata transaksi per hari hanya $12 .{ }^{37}$ Dari

\footnotetext{
36 Isna Fistiyanti, Wawancara, 9 Agustus 2018 di ruang Perpustakaan Pascasarjana.

37 Database perpustakaan pascasarjana UIN Sunan Ampel Surabaya, diakses melalui http//:pasca.uinsby.ac.id/catalog/admin/index.php. data diberikan oleh Isna Fistiyanti, petugas perpustakaan pascasarjana pada tanggal 9 Agustus 2018.
} 
sini jelaslah bahwa problem akses ke perpustakaan berada di penggunanya (mahasiswa). ${ }^{38}$

Berbeda dengan sumber offline, sumber online sudah disediakan oleh pihak UIN Sunan Ampel dan bisa diakses melalui jaringan internet UIN Sunan Ampel secara gratis. Meski langganan sumber online ini belum ke sumber online nomor wahid seperti Scopus, tetapi dukungan sumber sudah diberikan oleh penyelenggara. Sumber-sumber online yang sudah dilanggan tersebut antara lain: Ebsco, Springer, JSTOR, dan Wiley. ${ }^{39}$ Sepertinya, melihat rerata transaksi Perpustakaan Pascasarjana di atas, problem bukan terletak pada jumlah judul yang ada di perpustakaan semata, tetapi dorongan yang diberikan kepada mahasiswa untuk mengakses dan memanfaatkan sumber juga perlu dilakukan.

\section{Desain Kajian Islam Inter dan Multidisipliner di Pasca- sarjana UIN Sunan Ampel}

Pascasarjana UIN Sunan Ampel Surabaya dalam tahap mempersiapkan Naskah Akademik. ${ }^{40}$ Naskah ini disusun untuk memberikan penjelasan tentang relevansi antara Program Studi Ilmu Keislaman (Dirasah Islamiyah) pada jenjang pendidikan S3 dan perkembangan keilmuan Islam, baik dari segi subjek kajian maupun kerangka metodologis yang digunakan. Uraian dalam Naskah kademik ini berisi argumentasi akademis, justifikasi sosiologis dan juridis, ruang lingkup kajian serta kerangka metodologis bagi penyelenggaraan pendidikan program doktor di bidang Ilmu Keislaman pada Pascasarjana UIN Sunan Ampel Surabaya.

Dari sisi isinya, desain itu telah memberikan ketegasan terutama pada bagian D yang menjelaskan tentang Pendekatan Interdisipliner, Multidisipliner dan Transdisipliner (Ilmu-Ilmu Sosial) dalam Kajian Islam. Pada bagian itu diuraikan bahwa pada jenjang pendidikan tingkat lanjut, khususnya program doktor,

\footnotetext{
38 Pada saat orientasi mahasiswa baru, pengenalan dan tatacara akses perpustakaan sudah disampaikan kepada mahasiswa baru.

39 Lihat http://library.uinsby.ac.id/ selain beberapa langganan sumber online tersebut, perpustakaan juga menampilkan beberapa link online yang dapat digunakan oleh mahasiswa dalam memenuhi kebutuhan rujukan kajiannya.

${ }^{40}$ Naskah Akademik yang diterima peneliti masih dalam bentuk draft dan belum disahkan. Naskah diterima melalui wakil Direktur pascasarjana pada Kamis, 1 November 2018.
} 
kajian keilmuan, termasuk ilmu-ilmu keislaman, diarahkan untuk mengembangkan pendekatan yang bersifat interdisipliner, multidisipliner dan transdisipliner. Secara konseptual dan metodologis, pendekatan-pendekatan tersebut memiliki pengertian dan karakteristik yang beragam, dan kalangan sarjana mengembangkan pemahaman konseptual yang berbeda-beda. Namun demikian, ketiga pendekatan di atas memiliki ciri yang sama, yaitu penggunaan beberapa disiplin untuk mengkaji dan menganalisis suatu problem yang timbul dalam masyarakat secara ilmiah atau akademis. Perbedaannya terletak pada posisi setiap disiplin dan hubungan antardisiplin dalam menganalisis permasalahan yang dikaji atau diteliti.

Dalam pembahasan tentang interdisiplinaritas (dan pelbagai jenisnya atau bentuknya), penting kiranya mempertimbangkan Raymond Miller. ${ }^{41}$ Menurut Miller, istilah pendekatan interdisipliner digunakan untuk memayungi beberapa pendekatan, seperti multidisipliner, cross-disciplinary dan transdisipliner. Pendekatan interdisipliner merupakan konsep umum (generic) yang serba mencakup dan meliputi seluruh aktifitas yang menjajarkan (juxtapose), menggabungkan, mensintesiskan, menginterpretasikan atau melampaui bagian-bagian dari dua disiplin atau lebih.

Miller menyatakan bahwa pendekatan multidisipliner melibatkan penjajaran tetapi hanya sedikit menghubungkan antara disiplin-disiplin yang digunakan. Cross-disciplinary melibatkan interaksi yang nyata lintas disiplin, sekalipun tingkatan dan sifatnya sangat beragam atau bervariasi. Pendekatan transdisipliner menonjolkan model-model pemikiran yang menyeluruh untuk mengganti pandangan dunia disipliner yang ada. Pendekatan multidisipliner melibatkan tindakan sederhana menjajarkan beberapa disiplin tetapi tidak ada upaya sistematis untuk integrasi atau kombinasi. Akibatnya, komunikasi antardisiplin sangat lemah dan terbatas. Namun, jenis pendekatan multidisipliner ini lebih baik dari pada spesialisasi yang sempit dan terbatas.

Pendekatan cross-disciplinary oleh sebagian sarjana yang lain disebut juga sebagai pengertian generik dari pendekatan interdisipliner itu sendiri. Dinyatakan bahwa kelompok kajian crossdisciplinary terdiri dari orang-orang yang terlatih dalam lapangan

${ }^{41}$ Raymond C. Miller, "Varieties of Interdisciplinary Approaches in the Social Sciences", Issues in Integrative Studies, No. 1 (1982), 1-37. 
pengetahuan atau disiplin yang berbeda dengan konsep, metode, atau istilah-istilah yang berbeda-beda yang diorganisasikan ke dalam usaha bersama tentang problem yang sama dengan interaksi atau komunikasi terus-menerus.

Pendekatan cross-disciplinary mengimplikasikan penggunaan beberapa konsep, metode, atau teori dari pelbagai disiplin yang digunakan sebagai alat menganalisis data yang diperoleh tentang suatu topik, seperti sosiologi masyarakat (Islam) perkotaan, ekonomi masyarakat (muslim) kelas menengah dan seterusnya. Ada beberapa ciri atau komponen dari cross-disciplinary, dua yang menonjol di antaranya ialah bybrids dan grand synthesis. Hybrid melibatkan penggabungan bagian-bagian dari dua disiplin yang terkait untuk membentuk cross-disciplinary baru yang berusaha menjembatani kesenjangan antara beberapa disiplin, seperti psikologi sosial, antropologi ekonomi, sosiologi politik, kebudayaan dan kepribadian, sejarah ekonomi, dan lain sebagainya. Grand synthesis mencerminkan bahwa interdisiplinaritas merujuk kepada integrasi sistematis dari seluruh struktur atau susunan disipliner. Grand synthesis ini berbeda dari pandangan tentang penyatuan pengetahuan (unification of knowledge). Sementara itu, pendekatan transdisipliner, menurut Miller, merupakan kerangka konseptual yang terartikulasikan yang mengklaim melampaui lingkup pandangan dunia disipliner yang sempit dan secara metaforis mencakup bagian-bagian dari bidang kajian yang ditangani secara terpisah oleh disiplin yang terspesialisasi. Transdisiplinaritas adalah model pemikiran yang bersifat menyeluruh dan holistik, dan bermaksud untuk mereorganisasi struktur pengetahuan dalam ilmu-ilmu sosial dan bahkan juga bidang-bidang kajian keilmuan yang lain. Sebagian pendukung pendekatan transdisipliner mengklaim pendekatan ini sebagai alternatif dari pendekatan-pendekatan yang lain, meskipun sebagian pendukungnya yang lain lebih menyatakan pendekatan ini sebagai pelengkap bagi pendekatan cross-disciplinary.

Di antara pendekatan transdisipliner adalah pendekatan system theory (teori sistem), strukturalisme dan Marxisme, termasuk fenomenologi. Sejauh ini, pendekatan teori sistem dicirikan antara lain oleh homologi atau isomorfisme, sibernetik, makrodeterminisme dan holisme. Terdapat hirarki sistem yang strukturstrukturnya saling terkait dalam realitas sosial. Sedangkan 
strukturalisme menekankan pada saling-kait antara aspek-aspek dalam masyarakat, yang tunduk kepada hukum-hukum transformasi, struktur-struktur dan sistem sosial. Strukturalisme menggali struktur formal yang mendasari, struktur dalam yang dipercaya merefleksikan struktur pemikiran manusia yang dasar. Marxisme lebih memberikan tekanan pada kekuatan material bagi produksi dalam pembentukan masyarakat manusia termasuk manifestasi simboliknya, yang agak berbeda dari strukturalisme yang mencari struktur dalam pikiran atau kognisi manusia yang mempengaruhi bentuk kebiasaan atau institusi masyarakat manusia. Sementara itu, fenomenologi, seperti telah disebutkan di muka, menekankan kepada pencarian struktur kesadaran yang mempengaruhi pemikiran atau tindakan individu-individu manusia.

Dari deskripsi itu, jelas bahwa pendekatan kajian Islam inter dan multidisipliner di S3 Prodi Studi Islam (Dirasah Islamiyah) Pascasarjana UIN Sunan Ampel Surabaya, telah diatur secara tegas. Namun yang diperlukan adalah format implementatif dari pendekatan itu dalam proses perkuliahan. Perangkat perkuliahan yang menggambarkan pendekatan itu perlu dikembangkan sehingga dapat menjadi pegangan bagi dosen.

\section{Penutup}

Pemahaman stakeholder terhadap kajian Islam inter dan multidisipliner sebagian besar level manajemen, dosen, tenaga pendukung maupun mahasiswa di Pascasarjana UIN Sunan Ampel Surabaya sudah memahami dengan baik. Problematika impelementasi kajian Islam inter dan multidisipliner di Pascasarjana UIN Sunan Ampel Surabaya berada pada empat aspek, yakni: aspek mahasiswa, aspek dosen, aspek kurikulum, dan aspek daya dukung dan kebijakan. Mengingat implementasi aspek mahasiswa adalah raw material input, yang masuk studi ke jenjang S3 tidak semuanya memiliki kesiapan akademis untuk inter dan multidisipliner di samping problem bahasa dan psikologis. Problem implementasi aspek dosen adalah di samping terdapat dosen yang ideal memahami konsep perkuliahan dengan pendekatan inter dan multidisipliner, terdapat dosen yang kurang dapat memberikan dorongan kuat kepada mahasiswa dalam membuka cakrawala inter dan multidisipliner. Problem aspek kurikulum secara konsepsi, urutan pemberian matakuliah mulai dari semester satu hingga semester dua sudah cukup sistematis 
dalam mendorong mahasiswa untuk melakukan kajian Islam inter dan multidisipliner. Problem implementasi aspek daya dukung dan kebijakan adalah adanya prosedur administrasi yang rumit dan banyak, tanpa didukung oleh tenaga yang memadai, hal ini berakibat pada penjadwalan tahapan kegiatan akademis yang tidak efektif dan efisien.

Desain kajian Islam inter dan multidisipliner Studi Islam pada jenjang pendidikan S3 dan perkembangan keilmuan, berisi uraian dan argumentasi akademis, justifikasi sosiologis dan juridis, ruang lingkup kajian, serta kerangka metodologis bagi penyelenggaraan pendidikan program doktor Studi Islam pada Pascasarjana UIN Sunan Ampel Surabaya. Dari sisi isinya, desain itu telah memberikan ketegasan terutama pada bagian D yang menjelaskan tentang Pendekatan Interdisipliner, Multidisipliner dan Transdisipliner (Ilmu-Ilmu Sosial) dalam Kajian Islam, namun masih diperlukan adalah pengembangan format implementatif dari pendekatan itu dalam proses perkuliahan. Perangkat perkuliahan yang menggambarkan pendekatan itu perlu dikembangkan sehingga dapat menjadi pegangan bagi dosen.

Dari serentetan problematika yang dihadapi oleh mahasiswa dalam mengimplementasikan kajian inter dan multidisipliner di atas diperlukan langkah solutif dari pelaksana pendidikan S3 di Pascasarjana UIN Sunan Ampel Surabaya, dalam bentuk proses rekrutmen mahasiswa yang berorientasi pada dimungkinkannya penggalian terhadap penguasaan kompetensi keilmuan masa lalu secara komprehensif, melalui penelusuran dokumen, tes tulis, tes lisan dan penugasan berupa rencana proposal disertasi dengan menggunakan indikator penilaian yang berorientasi terhadap terpenuhinya aspek kajian Islam inter dan multidisipliner. Penilaian tidak saja didasarkan pada kompetensi bahasa Inggris dan Arab, tetapi juga kompetensi psikologis yang memberi petunjuk sejauh mana rasa keingintahuan dan potensi untuk bekerja keras dalam memperjuangkan arah keilmuan yang dimiliki. Dengan proses rekrutmen yang ketat diharapkan problem yang dialami mahasiswa sebagaimana dipaparkan di atas dapat dieliminir dengan baik.

Karena tidak meratanya pemahaman dosen akan kajian Islam inter dan multidisipliner maka hal penting yang mesti dilakukan oleh pengelola Pascasaraja adalah melakukan diseminasi secara merata terhadap dosen agar melakukan proses perkuliahan yang 
secara metodologis mengadopsi contoh baik pelaksanaan perkuliahan dengan pendekatan kajian inter dan multidisipliner seperti yang dilakukan oleh Amin Abdullah. Dengan membuat dokumen perangkat perkuliahan yang standar, memonitor dan mengevaluasi implementasinya dalam proses perkuliahan serta melakukan tindak lanjut dari hasil monitoring dan evaluasi yang dilakukan. Sehingga terdapat standar kualitas dosen yang mengedepankan implementasi kajian inter dan multidisipliner dalam perkuliahan.

Walaupun pihak pengelola Pascasarjana telah memberikan dukungan kurikulum yang dijadikan acuan untuk mengantarkan mahasiswa dalam menghasilkan karya kajian Islam yang inter dan multidisipliner, namun dukungan non-kurikuler perlu lebih ditingkatkan melalui kegiatan bimbingan teknis penulisan disertasi, kuliah umum, maupun seminar-seminar yang diselenggarakan oleh pascasarjana sebagai bekal pendukung dalam menyelesaikan studi. Hal lain yang disarankan dalam bagian ini adalah perlunya menetapkan arah riset inter, multi, dan transdisipliner yang dapat dipakai sebagai acuan mahasiswa dalam menyelesaikan tugas akhirnya. Arah riset ini penting sebagai cara menjawab pernyataan bahwa tidak keseluruhan mahasiswa yang menempuh pendidikan di kampus memiliki arah dan target-target yang pasti terkait studinya. Sebagian tentu ada yang merasa bahwa ini bernilai ibadah, sebagian yang lain merasa bahwa yang penting kuliah, sebagian lagi ada yang betul-betul memiliki rencana terkait riset yang akan dilakukannya. Kehadiran arah riset memberi jawaban dua kelompok mahasiswa yang tidak memiliki ketegasan riset.

\section{Daftar Rujukan}

Abdullah Amin. "Islam as a Cultural Capital in Indonesia and the Malay World: A Convergence of Islamic Studies, Social Sciences and Humanities", Journal of Indonesian Islam, Vol. 11, No. 2, 2017.

- Islamic Studies di Perguruan Tinggi: Pendekatan IntegrarifInterkonektif. Yogyakarta: Pustaka Pelajar, 2006.

Bahan Rujukan penulisan working paper seminar kelas matakuliah

Metodologi Studi Islam, Prof. M. Amin Abdullah, Semester Gasal 2017/2018

Dokumen Perkuliahan Seminar Proposal Dr. Phil. Khoirun Niam, 2018. 
Dokumen pribadi perkuliahan Sulanam, Mahasiswa S3 Angkatan 2017.

Hilmy, Masdar dan Muzakki, Akh. Dinamika Baru Studi Islam. Surabaya: Arkola, 2005.

http//:pasca.uinsby.ac.id/catalog/admin/index.php.

http://library.uinsby.ac.id/.

http://mpai.uinsby.ac.id/wp-

content/uploads/2018/08/pedoman-akademik-s2-s3_2018-

revised.pdf, diakses pada 27 Oktober 2018.

http://siakadpasca.uinsby.ac.id/akademik/siakad/index.php?page =list_kurikulum, diakses pada 27 Agustus 2018.

Miller, Raymond C. "Varieties of Interdisciplinary Approaches in the Social Sciences", Issues in Integrative Studies, No. 1, 1982.

Mudzhar, M. Atho. "In the Making of Islamic Studies in Indonesia (in Search for a Qiblah)", makalah disampaikan dalam seminar internasional Islam in Indonesia: Intellectualization and Social Transformation, Jakarta, 23-24 November 2000.

Musthofa, M. Luthfi dan Syaifuddin, Helmi (eds.). Intelektualisme Islam: Melacak Akar-akar Integrasi Ilmu dan Agama. Malang: LKQS, UIN Malang, 2007.

Naskah Akademik Program Studi Ilmu Keislaman (Dirasah Islamiyah) pada Jenjang Pendidikan Strata 3 (Program Doktor) dan Perkembangan Keilmuan Islam (Studi Islam).

Pascasarjana UIN Sunan Ampel Surabaya. Buku Pedoman Penyelenggaraan Pendidikan Pascasarjana UIN Sunan Ampel. Surabaya: UIN Sunan Ampel, 2018.

Peraturan Presiden Nomor 8 tahun 2012 tentang Kerangka Kualifikasi Nasional Indonesia (KKNI).

Program Pascasarjana UIN Sunan Ampel. Pedoman Penulisan Makalah, Proposal, Tesis, dan Disertasi UIN Sunan Ampel Surabaya. Surabaya: UIN Sunan Ampel Surabaya, 2018.

Program Pascasarjana UIN Sunan Ampel. Pedoman Penyelenggaraan Pendidikan Pascasarjana UIN Sunan Ampel Surabaya. Surabaya: UIN Sunan Ampel Surabaya, 2018.

Sulanam. "Dari Mengaji ke Mengkaji; Catatan Reflektif untuk Guruku, Profesor Amin Abdullah," tugas Catatan Reflektif untuk Matakuliah Metodologi Studi Islam, Semester Gasal 2017/2018. 
Syam, Nur. Membangun Keilmuan Islam Multidisipliner, http://nursyam.uinsby.ac.id/?p=754, diakses tanggal 6 Mei 2018.

Woodward, Mark. "Islamic and religious studies: Challenges and Opportunities for Twenty-first Century Indonesia", Journal of Indonesian Islam, Vol. 3, No. 1, 2009.

\section{Wawancara}

Ahmad Nur Fuad. Wawancara. Surabaya, 9 Agustus 2018

Isna Fistiyanti. Wawancara. Surabaya, 9 Agustus 2018

Mujib Ridlwan. Wawancara. Via telepon, 26 Agustus 2018

Mukhammad Zamzami. Wawancara. Surabaya, 9 dan 10 Agustus 2018

Ngatiyar. Wawancara. Via telepon, 27 Agustus 2018.

Abd. A'la. Wawancara. Surabaya, 10 Agustus 2018

Sulanam. Wawancara. 2 Agustus 2018. 